\title{
Prechlorination of algae-laden water: The effects of transportation time on cell integrity, algal organic matter release, and chlorinated disinfection byproduct formation
}

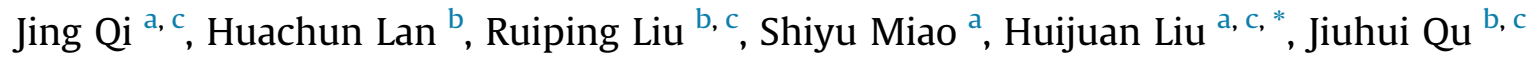 \\ a State Key Laboratory of Environmental Aquatic Chemistry, Research Center for Eco-Environmental Sciences, Chinese Academy of Sciences, Beijing, 100085, \\ China \\ ${ }^{\mathrm{b}}$ Key Laboratory of Drinking Water Science and Technology, Research Center for Eco-Environmental Sciences, Chinese Academy of Sciences, Beijing, 100085, \\ China \\ ${ }^{\mathrm{c}}$ University of Chinese Academy of Sciences, Beijing, 100049, China
}

\section{A R T I C L E I N F O}

\section{Article history:}

Received 6 April 2016

Received in revised form

11 June 2016

Accepted 17 June 2016

Available online 20 June 2016

\section{Keywords:}

Microcystis aeruginosa

Prechlorination

Transportation time

Cell integrity

Algal organic matter

Disinfection byproducts

\begin{abstract}
A B S T R A C T
The prechlorination-induced algal organic matter (AOM) released from Microcystis aeruginosa (M. aeruginosa) cells has been reported to serve as a source of precursors for chlorinated disinfection byproducts (DBPs). However, previous studies have mainly focused on the precursors either extracted directly from the cell suspension or derived immediately after algal suspension prechlorination. This study aims to investigate the impacts of water transportation time after algal suspension prechlorination on cell integrity, AOM release, and DBP formation during the dissolved phase chlorination. The damage to cell integrity after prechlorination was indicated to depend not only on chlorine dose but also on transportation time. The highest dissolved organic carbon (DOC) and dissolved organic nitrogen (DON) values were observed at $2 \mathrm{mg} / \mathrm{L}$ chlorine preoxidation before transportation, but were obtained at $0.4 \mathrm{mg} / \mathrm{L}$ chlorine after 480-min simulated transportation. The variation of DON with transportation time was indicated to be mainly influenced by the small molecular weight nitrogenous organic compounds, such as amino acids. Additionally, formation of the corresponding chlorinated carbonaceous disinfection byproducts (C-DBPs) and nitrogenous disinfection byproducts (N-DBPs) during the dissolved phase chlorination showed the same variation tendency as DOC and DON respectively. The highest C-DBP $(98.4 \mu \mathrm{g} / \mathrm{L})$ and N-DBP $(5.5 \mu \mathrm{g} / \mathrm{L})$ values were obtained at $0.4 \mathrm{mg} / \mathrm{L}$ chlorine preoxidation after 480 -min simulated transportation. Therefore, when prechlorination is applied for algae-laden water pretreatment, not only chlorine dose but also transportation time needs to be considered with regard to their effects on cell integrity, AOM release, and chlorinated DBP formation.
\end{abstract}

@ 2016 Published by Elsevier Ltd.

\section{Introduction}

Algae blooms worldwide have arisen increasing interest because of their negative effects on drinking water production. The traditional water treatment process cannot effectively remove algae due to their negatively-charged surface, diverse morphology, low specific density, and high motility (Pieterse and Cloot, 1997; Ma et al., 2007; Takaara et al., 2010). Chlorine, as a commonly used

\footnotetext{
* Corresponding author. State Key Laboratory of Environmental Aquatic Chemistry, Research Center for Eco-Environmental Sciences, Chinese Academy of Sciences, Beijing, 100085, China.

E-mail address: hjliu@rcees.ac.cn (H. Liu).
}

oxidant in algae-laden water preoxidation, has been applied at the intake points of water sources to improve algae removal (Shen et al., 2011). However, some studies have indicated that overdosed chlorine pretreatment may destroy cyanobacterial cells and result in the release of algal organic matter (AOM) to the water sources (Daly et al., 2007; Lin et al., 2009; Ma et al., 2012a).

The AOM released from Microcystis aeruginosa (M. aeruginosa) cells has been reported to serve as a source of precursors for disinfection byproducts (DBPs), not only carbonaceous disinfection byproducts (C-DBPs) such as trihalomethanes (THMs), halogen acetaldehyde (HAs), haloketone (HKs), and haloacetic acids (HAAs), but also nitrogenous disinfection byproducts (N-DBPs) such as haloacetonitriles (HANs), haloacetamides (HAcAms), and halogenated nitromethane (HNMs) (Plummer and Edzwald, 2001; Huang 
et al., 2009; Zhou et al., 2014a, 2015; Zhu et al., 2015). The formation potential of various C-DBPs and N-DBPs has been studied in detail for the chlorination of AOM extracted from algal cells (Lui et al., 2011; Yang et al., 2011). The prechlorination of algae-laden water has drawn great attention due to induced AOM release and DBP formation problems (Chiu and Wang, 2007). The release of numerous carbohydrates, proteinaceous compounds, and amino acids in AOM can eventually contribute to the chlorinated DBP formation because of their dissolved organic carbon (DOC) and dissolved organic nitrogen (DON) contents (Fang et al., 2010a, 2010b; Wert and Rosario-Ortiz, 2013). Additionally, AOM is rich in organic nitrogen (org- $\mathrm{N}$ ), and can produce higher quantities of $\mathrm{N}$ DBPs than the natural organic matter (NOM), i.e., humic acid, in chlorination (Fang et al., 2010b). The genotoxicity and carcinogenicity of N-DBPs are higher than those of C-DBPs, such as THMs and HAAs, resulting in the increasing interest in studying N-DBPs (Muellner et al., 2007; Richardson et al., 2007).

However, previous studies on AOM-induced DBP formation have mainly focused on precursors either extracted directly from the cell suspension or derived immediately by the filtration of preoxidized algal suspension (Zamyadi et al., 2012; Wert and Rosario-Ortiz, 2013; Zhou et al., 2014a), and cannot directly reflect or give guidance for practical water treatment scenarios. It should be noted that most highly algae-laden waters, i.e., those in reservoirs and lakes, are far away from drinking water treatment plants (DWTPs). It takes several to dozens of hours for the transportation of preoxidized raw water to DWTPs. The ratios of damaged cells after preoxidation can be increased by the extended transportation time (Qi et al., 2016). This would further influence the AOM release and chlorinated DBP formation process. Therefore, it is meaningful to investigate the impacts of transportation time after algal suspension prechlorination on AOM release and DBP formation during the dissolved phase chlorination.

Based on the aforementioned concerns, this study aims to: 1) investigate the effects of transportation time on algal cell integrity after prechlorination; 2 ) detect the prechlorination-induced variation of released AOM during simulated transportation; 3 ) evaluate chlorinated DBP formation from the prechlorination dose and transportation time aspects; 4) clarify the relationship between released AOM and DBP formation.

\section{Materials and methods}

\subsection{Materials and reagents}

The algae species used in this study was M. aeruginosa because of its prevalence in algae blooms and relevance to water quality and treatment challenges in waterworks (Kemp and John, 2006; Sano et al., 2011). M. aeruginosa (strain FACHB-905), previously described by Shen et al. (Shen and Song, 2007), was obtained from Wuhan Institute of Hydrobiology, Chinese Academy of Sciences, and cultured in BG-11 medium (Rippka et al., 1979). The detailed algae growth conditions are presented in Text S1. SYTOX green nucleic acid stain was purchased from Invitrogen, USA. Sodium hypochlorite ( $\mathrm{NaOCl}$, Sigma-Aldrich) stock solution and phosphate buffer solution (PBS; $10 \mathrm{mM}, \mathrm{pH}=7.5$ ) were prepared just before the experiments. Sodium thiosulfate $\left(\mathrm{Na}_{2} \mathrm{~S}_{2} \mathrm{O}_{3}\right)$ stock solution of $0.5 \mathrm{~g} / \mathrm{L}$ was prepared every week and stored in darkness. Nineteen amino acids (tryptophan, tyrosine, arginine, phenylalanine, histidine, methionine, glutamate, lysine, glutamine, aspartic acid, asparagine, leucine, isoleucine, threonine, valine, proline, serine, alanine, and glycine) were purchased from Sigma-Aldrich. Standard solutions of the studied DBPs were purchased from AccuStandard (USA).

\subsection{Experimental methods}

M. aeruginosa cultures were harvested at the exponential growth phase and then diluted with PBS after centrifugal cleaning (4500 rpm, $10 \mathrm{~min}$; three cycles of centrifugation and supernatant removal) to obtain the cell density of $1.0 \times 10^{6}$ cells $/ \mathrm{mL}$ for all experiments. In order to study the effects of prechlorination dose and simulated transportation time on the damage to cell integrity, release of AOM and formation of chlorinated DBPs, algal suspensions were rapidly mixed at $250 \mathrm{rpm}$ for $5 \mathrm{~min}$ after the addition of chlorine $(0,0.2,0.4,0.8,2 \mathrm{mg} / \mathrm{L}) ; \mathrm{Na}_{2} \mathrm{~S}_{2} \mathrm{O}_{3}$ was then added to quench the preoxidation, followed by slowly mixing at $40 \mathrm{rpm}$ for 0-480 min to simulate long-term transportation. All the experiments were conducted in the dark according to the practical transportation condition of raw water to drinking water treatment plants. In addition, the mixing speed of $80 \mathrm{rpm}$ was also conducted to check the influence of flow velocity on algal cell integrity after $0.2 \mathrm{mg} / \mathrm{L}$ chlorine preoxidation. Samples were siphoned after different mixing time $(0,30,60,120,240,480 \mathrm{~min})$ and divided in two subsamples: the first sample was evaluated for cell integrity detection. The remaining sample was immediately filtered through a $0.45 \mu \mathrm{m}$ glass fiber filter for the concentrations determination of DOC, DON, protein, and amino acids, and the subsequent experiments on chlorinated DBP formation.

The experiments assessing the chlorinated DBPs formed during the chlorination of the dissolved phase in preoxidized algal suspensions were carried out in amber glass bottles capped with Teflon-faced septa. The mass ratio of chlorine dosage $\left(\right.$ as $\left.\mathrm{Cl}_{2}\right)$ to DOC was 3:1. The chlorinated samples were maintained at $25 \pm 1{ }^{\circ} \mathrm{C}$ in the dark for $72 \mathrm{~h}$ and then quenched with ascorbic acid (SigmaAldrich) for the chlorinated DBP analyses.

\subsection{Analytical methods}

\subsubsection{Cell integrity detection}

Cell integrity was determined for individual cells using a flow cytometer (FACSCalibur 4CLR, BD Biosciences, San Jose, USA) equipped with an argon ion laser emitting at a fixed wavelength of $488 \mathrm{~nm}$ for fluorescence measurement. Full details of the cell integrity analysis are presented in Text S2. Scanning electron microscopy (SEM; SU-8020, Hitachi, Japan) was used to observe the morphologies of the cyanobacterial cells.

\subsubsection{Analysis of DOC and DON}

The DOC concentration in the dissolved phase of algal suspensions was measured with a Shimadzu TOC- $\mathrm{V}_{\mathrm{CPH}}$ analyzer. A FlowAccess continuous flow analyzer $\left(\mathrm{SAN}^{++}\right.$, SKALAR, Netherlands) was used to determine the nitrite, nitrate, and ammonia concentrations. DON concentrations were determined by subtracting the measured nitrite, nitrate, and ammonia concentrations from total nitrogen. The total nitrogen was analyzed as nitrate after potassium persulfate oxidation (Delia et al., 1977).

\subsubsection{Measurement of protein and amino acids}

Soluble protein was measured with a Micro BCA ${ }^{\mathrm{TM}}$ Protein Assay Kit (Thermo Scientific) (Smith et al., 1985). Identification and quantification of amino acids were carried out using an Agilent 1290 liquid chromatography system (Agilent, USA) equipped with a QQQ (Agilent6460, USA) tandem mass spectrometer. An ACQUITY UPLC $^{\mathbb{B}}$ HSS T3 column $(2.1 \mathrm{~mm} \times 100 \mathrm{~mm}, 1.8 \mu \mathrm{m})$ (Waters, USA) was used for separation. The total run time was $50 \mathrm{~min}$ for each sample. Other details of conditions can be found in Text S3.

\subsubsection{DBPs analysis}

Chloroform (TCM), chloral hydrate $(\mathrm{CH})$, dichloroacetone (DCP), 
trichloroacetone (TCP), dichloroacetonitrile (DCAN), trichloroacetonitrile (TCAN), dichloronitromethane (DCNM), and trichloronitromethane (TCNM) were determined by an Agilent 6890 gas chromatograph coupled with an electron capture detector (GC) ECD) (Agilent, USA) according to USEPA method 551.1 (Much and Hautman, 1995). Monochloroacetic acid (MCAA), dichloroacetic acid (DCAA), and trichloroacetic acid (TCAA) were pretreated with an extraction/derivatization procedure using methyl tert-butyl ether and acidic methanol, and analyzed by GC/ECD according to USEPA Method 552.3 (Domino et al., 2003). Dichloroacetamide (DCAcAm) and trichloroacetamide (TCACAm) were analyzed by liquid-liquid extraction and GC/MS detection (7890/7000B, Agilent, USA). Other conditions and the method detection limits can be found in Text S4.

\section{Results and discussion}

\subsection{Effects of simulated transportation time on cell integrity after prechlorination}

The effects of chlorine dose and simulated transportation time on algal cell integrity are shown in Fig. 1. Almost all the cyanobacterial cells maintained integrity even after 480-min simulated transportation without prechlorination. When the chlorine dose was $0.2 \mathrm{mg} / \mathrm{L}$, the ratio of damaged cells was $5 \%$ at $60 \mathrm{~min}$ after quenching chlorine, and then increased to $82 \%$ after $480 \mathrm{~min}$. Chlorine at $0.4 \mathrm{mg} / \mathrm{L}$ damaged $62 \%$ cyanobacterial cells after $60 \mathrm{~min}$, and $91 \%$ cyanobacterial cells lost integrity after $240 \mathrm{~min}$. More significant damage of cyanobacterial cells, i.e., $99 \%$, was observed at $2 \mathrm{mg} / \mathrm{L}$ chlorine at $60 \mathrm{~min}$ after quenching chlorine. The corresponding flow cytometry figures of all the algal cell integrity results can be found in Fig. S1.

The maintaining of cell integrity without prechlorination showed the stability of cyanobacterial cells in PBS, which has been used for algal suspension preparation in previous research (Wert et al., 2013). Chlorine at low dose, i.e., $0.2 \mathrm{mg} / \mathrm{L}$, mainly reacted with the surface-adsorbed AOM, and barely damaged cyanobacterial cells during 5-min preoxidation, as indicated from the low ratios of damaged cells. Previous studies have reported that chlorine can damage cyanobacterial cells, and that the damage extent is highly dependent on the chlorine dose and oxidation time (Wert

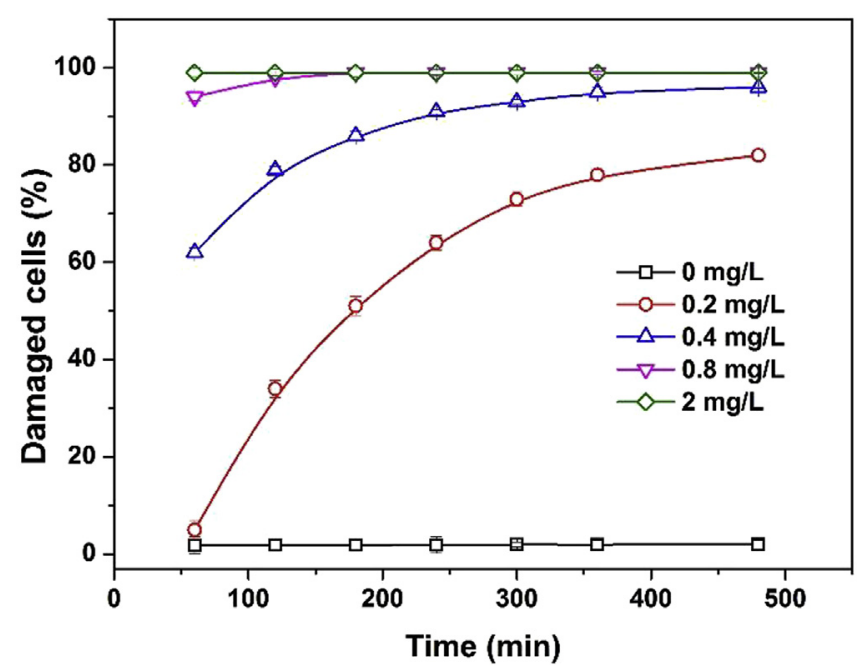

Fig. 1. Effects of chlorine dose and simulated transportation time on the damage to algal cell integrity. The results shown are mean data from triplicate experiments, and error bars indicate standard deviations based on triplicate analyses. et al., 2013; Fan et al., 2014). Interestingly, the ratios of damaged cells increased with the prolongation of transportation time, even though the residual chlorine was completely quenched. A similar finding has been reported for $\mathrm{KMnO}_{4}$ preoxidation with subsequent extended transportation time (Qi et al., 2016). This result can be explained by the programmed cell death (PCD) theory (Ross et al., 2006), which can induce the rapid collapse of algae (Kaneko et al., 2007; Frangeul et al., 2008). PCD can be caused by oxidative stress, ultraviolet irradiation, nutrient deprivation, salt stress, and heat (Bidle and Falkowski, 2004; Bidle et al., 2007), and finally lead the cells to perform genetically controlled cell suicide (Ameisen, 2002). Oxidative stress to cyanobacterial cells can be induced by chemical oxidants and cause PCD of cyanobacterial cells (Ding et al., 2012; Mikula et al., 2012).

These results demonstrate that the integrity of cyanobacterial cells after prechlorination is influenced not only by chlorine dose but also by the water transportation time from source water to DWTPs. Interestingly, the SEM result in Fig. S2 shows no morphology difference among cells subjected to various chlorine doses and simulated transportation time. This result is in accordance with previous studies reporting that chlorine can damage the cell integrity but not change the cell morphology (Lin et al., 2009; Ma et al., 2012b). Additionally, the algal cell integrity results got at mixing speed of $80 \mathrm{rpm}$ to simulate transportation after $0.2 \mathrm{mg} / \mathrm{L}$ chlorine preoxidation (Fig. S3) are almost the same as the ones we got at $40 \mathrm{rpm}$ in Fig. 1. This indicates that the slow mixing speed has little influence in the simulated transportation experiments.

\subsection{AOM release after prechlorination during simulated transportation}

Fig. 2 illustrates the effects of chlorine dose and simulated transportation time on the DOC and DON values of dissolved organic matter (DOM); chlorine at doses from 0 to $2 \mathrm{mg} / \mathrm{L}$ was added and the simulated transportation time varied from 0 to 480 min. All the DOC and DON values increased with the prolongation of simulated transportation time at fixed chlorine doses for preoxidation. When the time was less than $60 \mathrm{~min}$, the DOC values increased with the elevation of chlorine doses from 0 to $2 \mathrm{mg} / \mathrm{L}$. However, the DOC values showed an obvious increasing and then decreasing tendency with increasing chlorine dose at the prolonged simulated transportation times of 240 and $480 \mathrm{~min}$. The highest DOC value, i.e., $1.93 \mathrm{mg} / \mathrm{L}$, was obtained with $0.4 \mathrm{mg} / \mathrm{L}$ chlorine preoxidation at $480 \mathrm{~min}$ after quenching. Additionally, the DON values increased with increasing chlorine dose only if the simulated transportation time was less than $30 \mathrm{~min}$. Otherwise, the DON values showed an increasing and then decreasing tendency with increasing chlorine dose, and the highest DON values were also observed at $0.4 \mathrm{mg} / \mathrm{L}$ chlorine preoxidation after the same simulated transportation time.

The initial DOC value in the prepared algal suspension was determined to be $0.27 \mathrm{mg} / \mathrm{L}$, which might be due to the desorption of the loosely bound AOM on the cells (Xie et al., 2013). The increased DOC and DON values with prolongation of simulated transportation time were due not only to the further release of AOM from cyanobacterial cells damaged by prechlorination, but also to the rising ratios of damaged cells (Fig. 1). In addition, the decrease in DOC values with elevation of chlorine doses from 0.4 to $2 \mathrm{mg} / \mathrm{L}$ after the further prolonged simulated transportation time of 240 and 480 min might be due to the ability of highly damaged algal cells to accumulate organic materials via adsorption (Marungrueng and Pavasant, 2006; Salima et al., 2013). This means that the serious damage to cyanobacterial cells is unfavorable for the continuous release of AOM into the dissolved phase. Damaged algal cells have been found to be potential biosorbents because of their relatively 


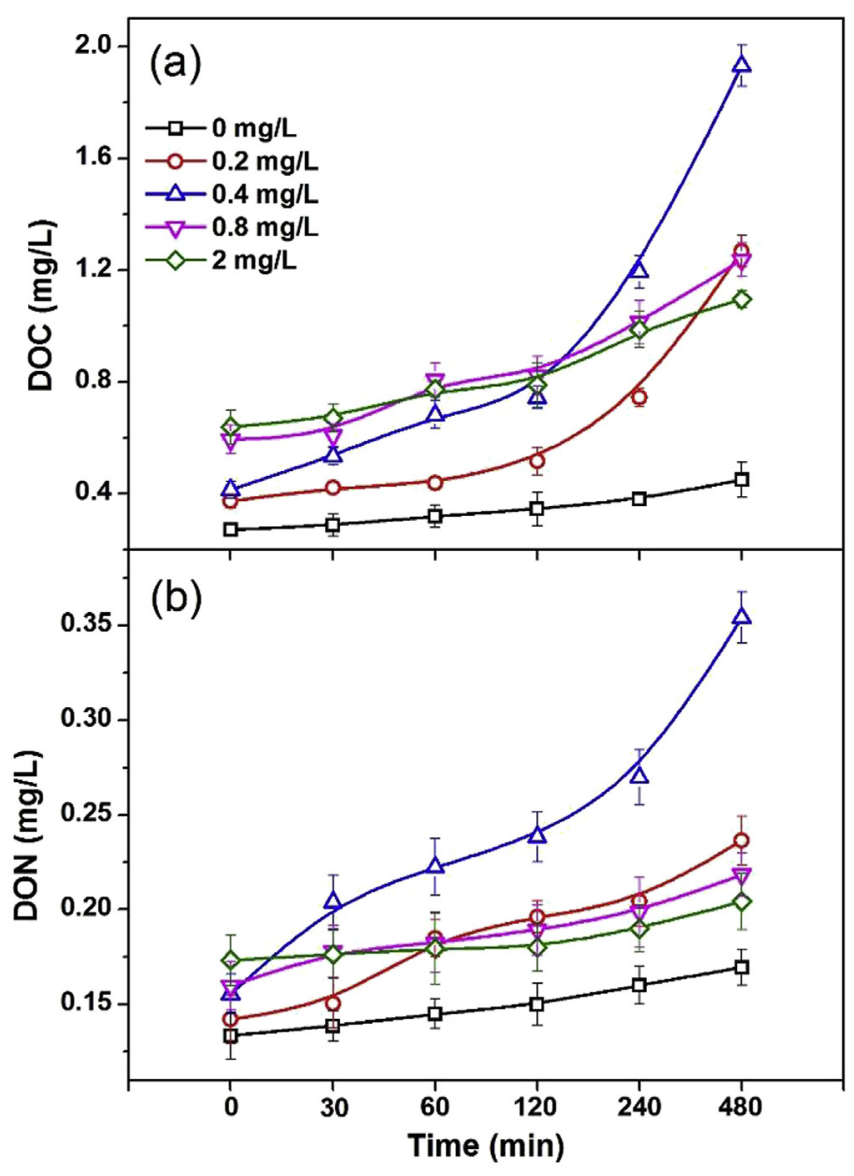

Fig. 2. Effects of chlorine dose on the (a) DOC and (b) DON values of DOM during simulated transportation time of $480 \mathrm{~min}$. The results shown are mean data from triplicate experiments, and error bars indicate standard deviations based on triplicate analyses.

large surface area and high binding affinity to adsorb polysaccharides and proteins (Aksu and Tezer, 2005). The biosorption function of damaged algal cells can be mainly explained by the changes of cell membrane structure and the physico-chemical adsorption process on cell surface (Tsezos and Bell, 1989; Tam et al., 2002). In addition, the membrane-bound organic matters released from damaged cells might further enhance the adsorption function (Avery et al., 1998).

The DON contents in AOM can contribute to the formation of $\mathrm{N}-$ DBPs (Wert and Rosario-Ortiz, 2013), which are more toxic than CDBPs (Muellner et al., 2007; Richardson et al., 2007). Proteins and amino acids are the main constituents of DON, and the amine structures in these compounds are very reactive toward chlorine (Morris, 1967). The effects of chlorine dose on the variation of detected protein and amino acid concentrations during simulated transportation time of 480 min were studied, as shown in Fig. 3, to further investigate the contributors to DON releasing tendency. In this study, nineteen amino acids were tested, and only the six amino acids arginine, methionine, serine, phenylalanine, tyrosine, and alanine were detectable. At all the fixed chlorine doses for preoxidation from 0 to $2 \mathrm{mg} / \mathrm{L}$, the prolongation of simulated transportation time showed less effect on the variations in protein concentrations compared with amino acids. In addition, the protein concentrations increased with increasing chlorine dose after the same simulated transportation time. However, the increment in amino acid concentrations occurred only if the chlorine dose was elevated from 0 to $0.4 \mathrm{mg} / \mathrm{L}$ at the fixed prolonged simulated

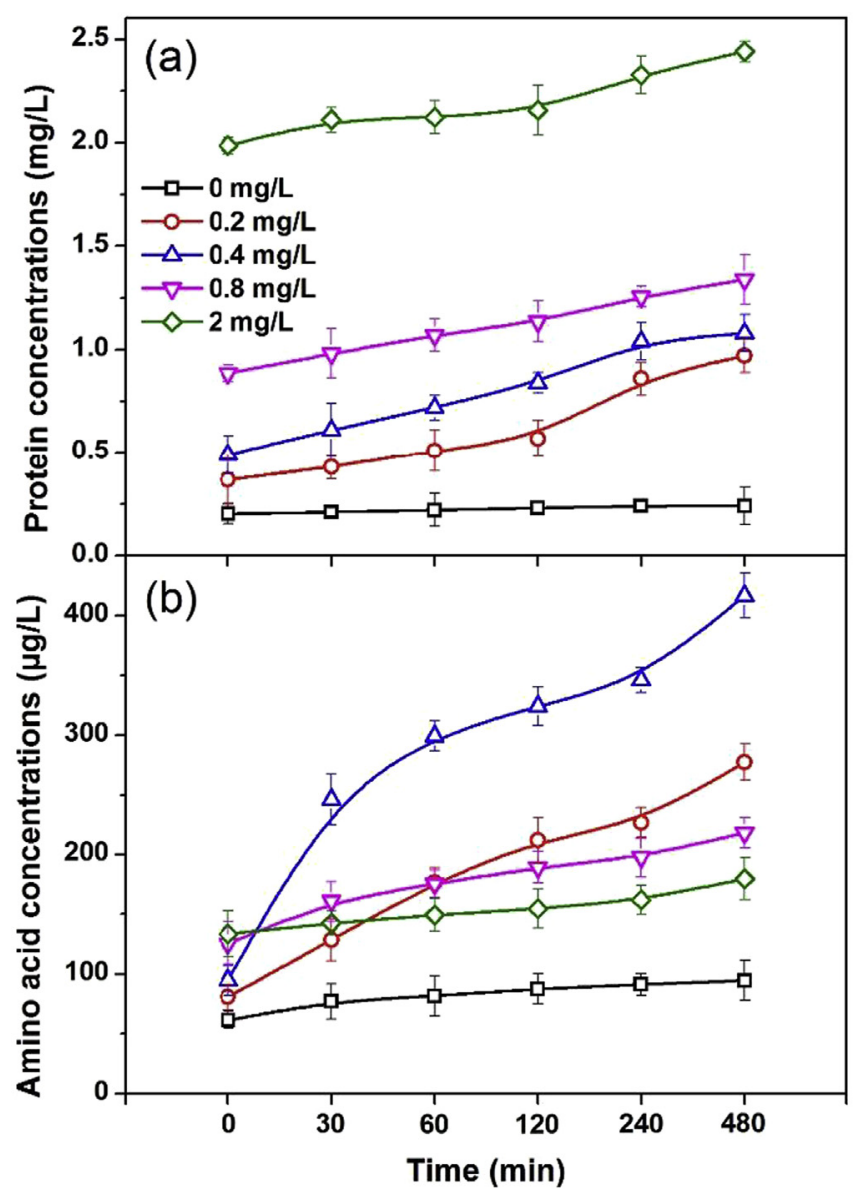

Fig. 3. Effects of chlorine dose on (a) protein concentrations and (b) amino acid concentrations in the dissolved phase during simulated transportation time of $480 \mathrm{~min}$. The results shown are mean data from triplicate experiments, and error bars indicate standard deviations based on triplicate analyses.

transportation time. Further elevated chlorine doses, i.e., 0.8 and $2 \mathrm{mg} / \mathrm{L}$, induced the decrease in amino acid concentrations.

Proteins and amino acids are the main DON contributors of dissolved AOM, and represent large and small molecular weight nitrogenous organic compounds respectively (Fang et al., 2010b). With the elevation of chlorine dose from 0 to $2 \mathrm{mg} / \mathrm{L}$, more proteins and amino acids were released into the solution because of the increasing amounts of damaged cells during prechlorination (Fig. 1). A previous study also reported that cell damage induced by elevated oxidant dose could promote protein and amino acid release (Xie et al., 2013). In addition, the proteins were mainly released during the preoxidation period, and prolongation of simulated transportation time did not have an obvious influence on the protein concentrations. This indicates that the further increase of protein concentrations is inhibited due to the binding function of damaged cyanobacterial cells (Aksu and Tezer, 2005). However, the further increased amino acid concentrations at fixed chlorine doses, i.e., $0.2 \mathrm{mg} / \mathrm{L}$ and $0.4 \mathrm{mg} / \mathrm{L}$, showed that amino acids could be further released into the solution during the simulated transportation period. Amino acids are more hydrophilic compared with proteins (Gilbert, 2000), which is beneficial for their release into aqueous phase. Additionally, the less molecular weight amino acids are not easy to be adsorbed by slightly damaged cells because of the weak attractive force for physical adsorption (Tchobanoglous et al., 1978). Amino acids were reported to be the main component of the small molecular weight nitrogenous organic compounds in IOM 
(Fang et al., 2010b). Combined with the DON result in Fig. 2b, the amino acids showed the same tendency, which means that the DON variation is mainly influenced by the small molecular weight nitrogenous organic compounds rather than the large ones.

\subsection{Effects of prechlorination and simulated transportation time on chlorinated DBP formation}

Fig. 4a shows the effects of simulated transportation time and chlorine dose on the C-DBPs formed during the chlorination of the dissolved phase in preoxidized algal suspensions. Our results from chlorinated AOM indicated that TCM, CH, DCAA, and TCAA are the predominant chlorinated C-DBPs. When the time was less than $30 \mathrm{~min}$, the detected C-DBPs increased with the elevation of chlorine doses from 0 to $2 \mathrm{mg} / \mathrm{L}$. With the prolonged simulated transportation time of 240 and $480 \mathrm{~min}$, the C-DBP values showed an obvious increasing and then decreasing tendency with increasing chlorine doses. The detected C-DBPs increased with the prolongation of simulated transportation time at fixed chlorine dose for preoxidation (Fig. S4a). The highest total C-DBP value was obtained with $0.4 \mathrm{mg} / \mathrm{L}$ chlorine preoxidation followed by $480-\mathrm{min}$ simulated transportation time, which represented an increase of $200 \%$ compared with the value without simulated transportation, while only a $46 \%$ increase occurred for the chlorine dosage of $2 \mathrm{mg} / \mathrm{L}$.

The effects of chlorine dose and simulated transportation time on the variation of N-DBP concentrations were also investigated (Fig. 4b). The predominant chlorinated N-DBPs were DCAN, DCAcAm, TCNM, TCACAm, and DCNM in the formed N-DBPs. An increase in detected N-DBP concentrations with elevation of chlorine dose occurred only if the simulated transportation time was less than $30 \mathrm{~min}$. Further prolonged simulated transportation time induced the decrease in N-DBP concentrations with elevated chlorine doses of 0.8 and $2 \mathrm{mg} / \mathrm{L}$. The detected N-DBP concentrations increased with the increasing simulated transportation time at all fixed chlorine doses (Fig. S4b). The concentration of total NDBPs at chlorine dosage of $0.4 \mathrm{mg} / \mathrm{L}$ increased monotonically from 1.3 to $5.5 \mu \mathrm{g} / \mathrm{L}$ with prolongation of simulated transportation time from 0 to $480 \mathrm{~min}$, while it increased from 1.7 to $2.3 \mu \mathrm{g} / \mathrm{L}$ at the chlorine dosage of $2 \mathrm{mg} / \mathrm{L}$.

The reactivity of AOM as precursors of chlorinated DBPs has been evaluated by many studies (Fang et al., 2010a, 2010b; Li et al., 2012; Wert and Rosario-Ortiz, 2013). The AOM released from $M$. aeruginosa with prolonged simulated transportation time after prechlorination can result in a dramatic increase of DBPs formed during chlorination of the dissolved phase. The C-DBP and N-DBP values were in good agreement with DOC and DON respectively, and showed good linear relationships (Fig. S5 and S6). When the simulated transportation time was prolonged to $480 \mathrm{~min}$, the measured DOC increased $1.48 \mathrm{mg} / \mathrm{L}$ with the elevated chlorine dose from 0 to $0.4 \mathrm{mg} / \mathrm{L}$, which increased the formation of C-DBPs by $211 \%$. These results indicate that the DOC released during prolonged transportation time after preoxidation of the algal suspension is the main contributor to C-DBP variation. This result is consistent with previous findings that higher DOC resulted in higher C-DBP formation (Wert and Rosario-Ortiz, 2013; Zhou et al., 2014b). In addition, the DON variation result was inferred to be mainly influenced by the small molecular weight nitrogenous organic compounds, which finally resulted in the observed variation in N-DBPs. Besides, the DBPs formed during the prechlorination period were all found to be C-DBPs, and the highest total DBP concentration of $5.7 \mu \mathrm{g} / \mathrm{L}$ was obtained after 5-min preoxidation with $2 \mathrm{mg} / \mathrm{L}$ chlorine (Fig. S7). The total DBP concentrations formed after preoxidation increased with the elevation of chlorine dose. During the preoxidation period, chlorine could not only destroy the cell membrane and induce cell damage, but also react with AOM and induce DBP formation (Chiu and Wang, 2007; Chao-An and Gen-Shuh, 2008; Zamyadi et al., 2013). The results are similar to those of previous studies, which reported that DBPs increased with the elevation of chlorine dose (Zhou et al., 2014b).

\subsection{Proposed influence pathway}

The above results indicate that the effects of prechlorination on cell integrity, AOM release, and chlorinated DBP formation can be influenced by the transportation time. On the basis of the results, a proposed influence pathway is illustrated in Fig. 5.

After the algal suspension is dosed with chlorine, the chlorine mainly influences the cyanobacterial cells through two pathways: (1) penetrating the cell membrane and destroying the chromophores; (2) inactivating cyanobacterial cells and resulting in AOM release (Ma et al., 2012b). Despite there being no observable difference in the algal cell morphology with and without prechlorination (Fig. S2), the amount of AOM released during prechlorination increased with the elevation of chlorine dose. This can be explained by the damaged algal cell integrity, especially after over-dosed chlorine pretreatment (Fig. 1).

For the lower-dosed chlorine pretreatment, prolonged transportation time can induce not only further release of AOM but also more damage to cell integrity, by the aforementioned PCD theory. However, the highly damaged cyanobacterial cells induced by overdosed chlorine pretreatment can exhibit an adsorption function during long-time transportation, and lead to lower amounts of AOM in the dissolved phase compared with the lower-dosed chlorine pretreatment (Fig. 2). The highly damaged algal cells have the ability to accumulate organic materials via adsorption (Marungrueng and Pavasant, 2006; Salima et al., 2013), due to their relatively large surface area and the physico-chemical adsorption process on cell surface (Tsezos and Bell, 1989; Tam et al., 2002; Aksu and Tezer, 2005). The amino acid concentrations in Fig. 3 showed the same tendency with DON variation results. However, only slight increase of protein concentrations occurred with the prolonged simulated transportation time at all the fixed chlorine dose. Proteins are less hydrophilic and have high molecular weight compared with amino acids (Gilbert, 2000), which are unfavourable for their further release into the solution during the simulated transportation period.

The total chlorinated C-DBPs and N-DBPs formed in the dissolved phase chlorination is illustrated in contour plot format according to the results in Fig. 4. It is clear that more DBPs were formed for the lower-dosed chlorine pretreatment with prolonged transportation time. As remarkable amounts of AOM in the dissolved phase can result in increasing chlorinated DBP formation (Plummer and Edzwald, 2001; Huang et al., 2009), both the chlorine dose and transportation time need to be considered for the application of prechlorination in algae-laden water pretreatment.

\section{Conclusions}

This study provides useful information regarding the effects of water transportation time after algal suspension prechlorination on cell integrity, AOM release and chlorinated DBP formation. The damage to cell integrity after prechlorination, especially after lower-dosed chlorine preoxidation, was found to increase with the transportation time. After 480-min simulated transportation, the higher DOC and DON concentrations were observed for preoxidation at lower chlorine dosages. In addition, the variation in DON with transportation time was mainly induced by small molecular weight nitrogenous organic compounds. Moreover, the chlorinated C-DBPs and N-DBPs after preoxidation showed the same tendencies as DOC and DON respectively. These findings indicate that 

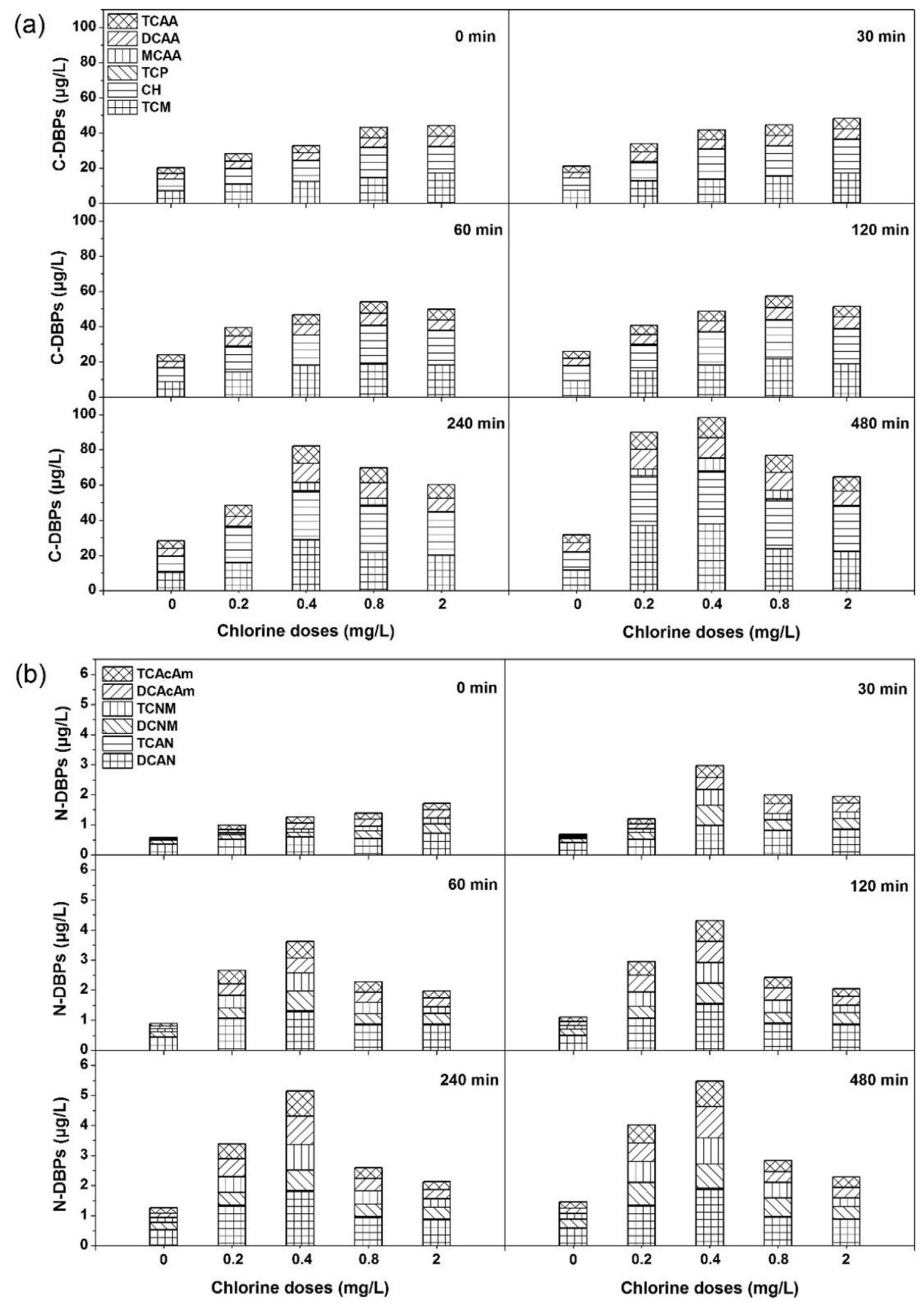

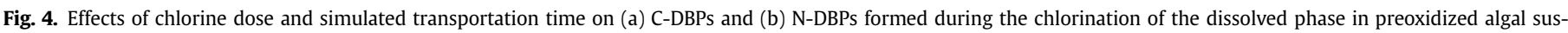
pensions. The results shown are mean data from triplicate experiments. 

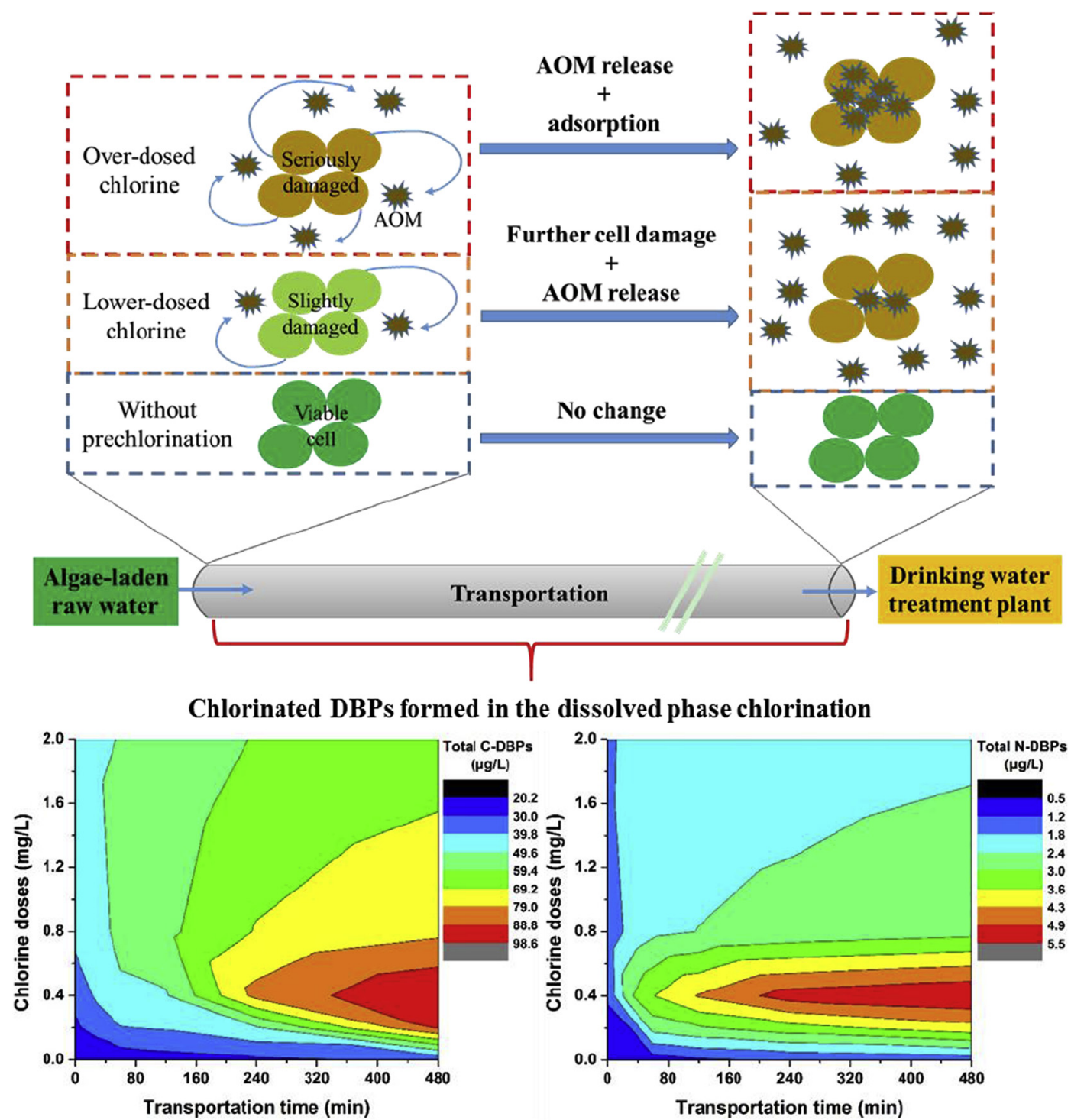

Fig. 5. The diagram of prechlorination effects on cell integrity, AOM release and chlorinated DBP formation during simulated transportation time.

both chlorine dose and transportation time need to be considered before applying prechlorination in the pretreatment of algae-laden water. It should be noted that all the findings were obtained in PBS with laboratory-cultured $M$. aeruginosa. Further verification is needed to generalize the findings to other algae species and actual water bodies utilizing the methods demonstrated in this study.

\section{Acknowledgements}

This work was supported by the National Science Fund for Distinguished Young Scholars of China (Grant No. 51225805) and the National Natural Science Foundation of China (Grant No. 51422813).

\section{Appendix A. Supplementary data}

Supplementary data related to this article can be found at http:/ dx.doi.org/10.1016/j.watres.2016.06.039.

\section{References}

Aksu, Z., Tezer, S., 2005. Biosorption of reactive dyes on the green alga Chlorella vulgaris. Process Biochem. 40 (3-4), 1347-1361.

Ameisen, J.C., 2002. On the origin, evolution, and nature of programmed cell death: a timeline of four billion years. Cell Death Differ. 9 (4), 367-393.

Avery, S.V., Codd, G.A., Gadd, G.M., 1998. Microalgal removal of organic and inorganic metal species from aqueous solution. In: Wong, Y.S., Tam, N.F.Y. (Eds.), Wastewater Treat. Algae. Springer-Verlag Berlin, Berlin, Heidelberg, pp. 55-72.

Bidle, K.D., Falkowski, P.G., 2004. Cell death in planktonic, photosynthetic microorganisms. Nat. Rev. Microbiol. 2 (8), 643-655.

Bidle, K.D., Haramaty, L., Barcelos e Ramos, J., Falkowski, P., 2007. Viral activation and recruitment of metacaspases in the unicellular coccolithophore, Emiliania huxleyi. Proc. Natl. Acad. Sci. U. S. A. 104 (14), 6049-6054.

Chao-An, C., Gen-Shuh, W., 2008. Pre-chlorination induced DOC and DBPs formation from Microcystis aeruginosa in treatment processes. ACS Symp. Ser. 995, $141-156$.

Chiu, C.-A., Wang, G.-S., 2007. Pre-chlorination-induced DOC and DBPs' formation from M. aeruginosa in water treatment processes. Abstr. Pap. Am. Chem. Soc. $233,540,540$

Daly, R.I., Ho, L., Brookes, J.D., 2007. Effect of chlorination on Microcystis aeruginosa cell integrity and subsequent microcystin release and degradation. Environ. Sci. Technol. 41 (12), 4447-4453.

Delia, C.F., Steudler, P.A., Corwin, N., 1977. Determination of total nitrogen in aqueous samples using persulfate digestion. Limnol. Oceanogr. 22 (4), 760-764.

Ding, Y., Gan, N.Q., Li, J., Sedmak, B.J., Song, L.R., 2012. Hydrogen peroxide induces apoptotic-like cell death in Microcystis aeruginosa (Chroococcales, 
Cyanobacteria) in a dose-dependent manner. Phycologia 51 (5), 567-575.

Domino, M., Pepich, B., Munch, D., Fair, P., Xie, Y., 2003. USEPA Method 552.3 Determination of Haloacetic Acids and Dalapon in Drinking Water by Liquidliquid Microextraction, Derivatization, and Gas Chromatography with Electron Capture Detection. Office of Ground Water and Drinking Water, Cincinnati, Ohio.

Fan, J.J., Hobson, P., Ho, L., Daly, R., Brookes, J., 2014. The effects of various control and water treatment processes on the membrane integrity and toxin fate of cyanobacteria. J. Hazard. Mater. 264, 313-322.

Fang, J.Y., Ma, J., Yang, X., Shang, C., 2010a. Formation of carbonaceous and nitrogenous disinfection by-products from the chlorination of Microcystis aeruginosa. Water Res. 44 (6), 1934-1940.

Fang, J.Y., Yang, X., Ma, J., Shang, C., Zhao, Q.A., 2010b. Characterization of algal organic matter and formation of DBPs from chlor(am)ination. Water Res. 44 (20), 5897-5906.

Frangeul, L., Quillardet, P., Castets, A.-M., Humbert, J.-F., Matthijs, H.C.P., Cortez, D., Tolonen, A., Zhang, C.-C., Gribaldo, S., Kehr, J.-C., Zilliges, Y., Ziemert, N., Becker, S., Talla, E., Latifi, A., Billault, A., Lepelletier, A., Dittmann, E., Bouchier, C., de Marsac, N.T., 2008. Highly plastic genome of Microcystis aeruginosa PCC 7806, a ubiquitous toxic freshwater cyanobacterium. Bmc Genom. 9.

Gilbert, H.F., 2000. Protein Structure. Basic Concepts in Biochemistry. Zollo, S. and Holton, B., McGraw-Hill, New York St. Louis San Francisco, pp. 6-21.

Huang, J., Graham, N., Templeton, M.R., Zhang, Y., Collins, C., Nieuwenhuijsen, M., 2009. A comparison of the role of two blue-green algae in THM and HAA formation. Water Res. 43 (12), 3009-3018.

Kaneko, T., Nakajima, N., Okamoto, S., Suzuki, I., Tanabe, Y., Tamaoki, M. Nakamura, Y., Kasai, F., Watanabe, A., Kawashima, K., Kishida, Y., Ono, A. Shimizu, Y., Takahashi, C., Minami, C., Fujishiro, T., Kohara, M., Katoh, M., Nakazaki, N., Nakayama, S., Yamada, M., Tabatai, S., Watanabe, M.M., 2007. Complete genomic structure of the bloom-forming toxic cyanobacterium Microcystis aeruginosa NIES-843. DNA Res. 14 (6), 247-256.

Kemp, A., John, J., 2006. Microcystins associated with microcystis dominated blooms in the southwest wetlands, Western Australia. Environ. Toxicol. 21 (2), 125-130.

Li, L., Gao, N.Y., Deng, Y., Yao, J.J., Zhang, K.J., 2012. Characterization of intracellular \& extracellular algae organic matters (AOM) of Microcystic aeruginosa and formation of AOM-associated disinfection byproducts and odor \& taste compounds. Water Res. 46 (4), 1233-1240.

Lin, T.-F., Chang, D.-W., Lien, S.-K., Tseng, Y.-S., Chiu, Y.-T., Wang, Y.-S., 2009. Effect of chlorination on the cell integrity of two noxious cyanobacteria and their releases of odorants. J. Water Supply Res. Technol. AQUA 58 (8), 539-551.

Lui, Y.S., Qiu, J.W., Zhang, Y.L., Wong, M.H., Liang, Y., 2011. Algal-derived organic matter as precursors of disinfection by-products and mutagens upon chlorination. Water Res. 45 (3), 1454-1462.

Ma, J., Lei, G.Y., Fang, J.Y., 2007. Effect of algae species population structure on their removal by coagulation and filtration processes - a case study. J. Water Supply Res. Technol. Aqua 56 (1), 41-54.

Ma, M., Liu, R.P., Liu, H.J., Qu, J.H., 2012b. Chlorination of Microcystis aeruginosa suspension: cell lysis, toxin release and degradation. J. Hazard. Mater. 217, 279-285.

Ma, M., Liu, R.P., Liu, H.J., Qu, J.H., Jefferson, W., 2012a. Effects and mechanisms of pre-chlorination on Microcystis aeruginosa removal by alum coagulation: Significance of the released intracellular organic matter. Sep. Purif. Technol. 86, 19-25.

Marungrueng, K., Pavasant, P., 2006. Removal of basic dye (Astrazon Blue FGRL) using macroalga Caulerpa lentillifera. J. Environ. Manag. 78 (3), 268-274.

Mikula, P., Zezulka, S., Jancula, D., Marsalek, B., 2012. Metabolic activity and membrane integrity changes in Microcystis aeruginosa - new findings on hydrogen peroxide toxicity in cyanobacteria. Eur. J. Phycol. 47 (3), 195-206.

Morris, J.C., 1967. Kinetics of reactions between aqueous chlorine and organic compounds. In: Principles and Applications of Water Chemistry. John Wiley \& Sons, New York, pp. 23-53.

Much, J.W., Hautman, D.P., 1995. USEPA Method 551.1 Determination of Chlorination Disinfection by products, Chlorinated Solvents, and Halogenated Pesticides/herbicides in Drinking Water by Liquid-liquid Extraction and Gas Chromatography with Electron-capture Detection. Office of Research and Development, Washington, DC.

Muellner, M.G., Wagner, E.D., McCalla, K., Richardson, S.D., Woo, Y.-T., Plewa, M.J., 2007. Haloacetonitriles vs. regulated haloacetic acids: are nitrogen-containing DBPs more toxic? Environ. Sci. Technol. 41 (2), 645-651.

Pieterse, A., Cloot, A., 1997. Algal cells and coagulation, flocculation and sedimentation processes. Water Sci. Technol. 36 (4), 111-118.

Plummer, J.D., Edzwald, J.K., 2001. Effect of ozone on algae as precursors for trihalomethane and haloacetic acid production. Environ. Sci. Technol. 35 (18) 3661-3668.

Qi, J., Lan, H.C., Miao, S.Y., Xu, Q., Liu, R.P., Liu, H.J., Qu, J.H., 2016. KMnO $4-F e(I I)$ pretreatment to enhance Microcystis aeruginosa removal by aluminum coagulation: does it work after long distance transportation? Water Res. 88, 127-134.

Richardson, S.D., Plewa, M.J., Wagner, E.D., Schoeny, R., DeMarini, D.M., 2007. Occurrence, genotoxicity, and carcinogenicity of regulated and emerging disinfection by-products in drinking water: a review and roadmap for research. Mutat. Research-Reviews Mutat. Res. 636 (1-3), 178-242.

Rippka, R., Deruelles, J., Waterbury, J.B., Herdman, M., Stanier, R.Y., 1979. Generic assignments, strain histories and properties of pure cultures of cyanobacteria. J. General Microbiol. 111 (MAR), 1-61.

Ross, C., Santiago-Vázquez, L., Paul, V., 2006. Toxin release in response to oxidative stress and programmed cell death in the cyanobacterium Microcystis aeruginosa. Aquat. Toxicol. 78 (1), 66-73.

Salima, A., Benaouda, B., Noureddine, B., Duclaux, L., Marungrueng, K., Pavasant, P., 2013. Application of Ulva lactuca and Systoceira stricta algae-based activated carbons to hazardous cationic dyes removal from industrial effluents. Water Res. 47 (10), 3375-3388.

Sano, D. Ishifuji, S., Sato, Y., Imae, Y., Takaara, T., Masago, Y., Omura, T., 2011. Identification and characterization of coagulation inhibitor proteins derived from cyanobacterium Microcystis aeruginosa. Chemosphere 82 (8), 1096-1102.

Shen, H. Song, L.R., 2007. Comparative studies on physiological responses to phosphorus in two phenotypes of bloom-forming Microcystis. Hydrobiologia 592, 475-486.

Shen, Q.H., Zhu, J.W., Cheng, L.H., Zhang, J.H., Zhang, Z., Xu, X.H., 2011. Enhanced algae removal by drinking water treatment of chlorination coupled with coagulation. Desalination 271 (1-3), 236-240.

Smith, P.K., Krohn, R.I., Hermanson, G.T., Mallia, A.K., Gartner, F.H., Provenzano, M.D. Fujimoto, E.K., Goeke, N.M., Olson, B.J., Klenk, D.C., 1985. Measurement of protein using bicinchoninic acid. Anal. Biochem. 150 (1), 76-85.

Takaara, T., Sano, D., Masago, Y., Omura, T., 2010. Surface-retained organic matter of Microcystis aeruginosa inhibiting coagulation with polyaluminum chloride in drinking water treatment. Water Res. 44 (13), 3781-3786.

Tam, N.F.Y., Chong, A.M.Y., Wong, Y.S., 2002. Removal of tributyltin (TBT) by live and dead microalgal cells. Mar. Pollut. Bull. 45 (1-12), 362-371.

Tchobanoglous, G., Burton, F.L., Stensel, H.D., 1978. Advanced Wastewater Treatment. Wastewater Engineering: Treatment and Reuse. McGraw-Hill, New York St. Louis San Francisco, pp. 749-877.

Tsezos, M., Bell, J.P., 1989. Comparison of the biosorption and desorption of hazardous organic pollutants by live and dead biomass. Water Res. 23 (5) $561-568$.

Wert, E.C., Dong, M.M., Rosario-Ortiz, F.L., 2013. Using digital flow cytometry to assess the degradation of three cyanobacteria species after oxidation processes. Water Res. 47 (11), 3752-3761.

Wert, E.C., Rosario-Ortiz, F.L., 2013. Intracellular organic matter from Cyanobacteria as a precursor for carbonaceous and nitrogenous disinfection byproducts. Environ. Sci. Technol. 47 (12), 6332-6340.

Xie, P.C., Ma, J., Fang, J.Y., Guan, Y.H., Yue, S.Y., Li, X.C., Chen, L.W., 2013. Comparison of permanganate preoxidation and preozonation on algae containing water: cell Integrity, characteristics, and chlorinated disinfection byproduct formation. Environ. Sci. Technol. 47 (24), 14051-14061.

Yang, X., Guo, W.H., Shen, Q.Q., 2011. Formation of disinfection byproducts from chlor(am)ination of algal organic matter. J. Hazard. Mater. 197, 378-388.

Zamyadi, A., Fan, Y., Daly, R.I., Prévost, M., 2013. Chlorination of Microcystis aeruginosa: toxin release and oxidation, cellular chlorine demand and disinfection by-products formation. Water Res. 47 (3), 1080-1090.

Zamyadi, A., Ho, L., Newcombe, G., Bustamante, H., Prévost, M., 2012. Fate of toxic cyanobacterial cells and disinfection by-products formation after chlorination. Water Res. 46 (5), 1524-1535.

Zhou, S.Q., Shao, Y.S., Gao, N.Y., Deng, Y., Li, L., Deng, J., Tan, C.Q., 2014a. Characterization of algal organic matters of Microcystis aeruginosa: biodegradability, DBP formation and membrane fouling potential. Water Res. 52, 199-207.

Zhou, S.Q., Shao, Y.S., Gao, N.Y., Li, L., Deng, J., Zhu, M.Q., Zhu, S.M., 2014b. Effect of chlorine dioxide on cyanobacterial cell integrity, toxin degradation and disinfection by-product formation. Sci. Total Environ. 482, 208-213.

Zhou, S.Q., Zhu, S.M., Shao, Y.S., Gao, N.Y., 2015. Characteristics of C-, N-DBPs formation from algal organic matter: role of molecular weight fractions and impacts of pre-ozonation. Water Res. 72, 381-390.

Zhu, M.Q., Gao, N.Y., Chu, W.H., Zhou, S.Q., Zhang, Z.D., Xu, Y.Q., Dai, Q., 2015. Impact of pre-ozonation on disinfection by-product formation and speciation from chlor(am)ination of algal organic matter of Microcystis aeruginosa. Ecotoxicol. Environ. Saf. 120, 256-262. 